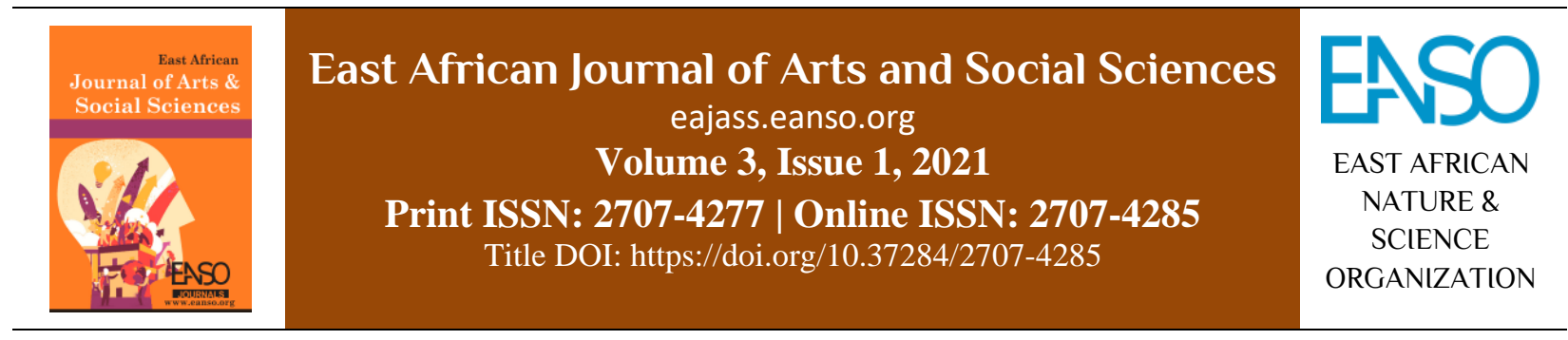

Original Article

\title{
The Clamour for an End to Police Brutality: Satire Songs of the EndSars Protests in Nigeria
}

\author{
Tolu Owoaje, $P h D^{1 *} \&$ Kadupe Sofola ${ }^{1}$ \\ ${ }^{1}$ Department of Music, University of Ibadan, PMB 5116, Ibadan, Nigeria. \\ * ORCID: https://orcid.org/0000-0002-5007-0846; Correspondance email: toluowoaje@ yahoo.com.
}

Article DOI: https://doi.org/10.37284/eajass.3.1.315

\section{Date Published: ABSTRACT}

07 April 2021 The EndSars protests, which occurred in Nigeria in October 2020 employed a

Keywords: songs. This article investigates the use of satirical songs in the EndSars protests.

The protest, which recorded a massive turnout of protesters in October 2020

Police Brutality, across major cities in Nigeria started several months on the social media, most

Satire, especially Twitter, a microblogging website before it was finally taken to the

Satirical Songs,

Nigerian Police Force.

streets. Anchored on the concept of social movement, it employs the use of participant observation and the social media platforms to gather data which were analysed using content analysis. Apart from being used to ridicule the Nigerian Police which has not engaged Boko-Haram terrorists but instead unleashes terror on harmless youths, satirical songs were used by protesters to express their long piled up anger at the Federal Government of Nigeria. This is due to several unfulfilled campaign promises, as well as the bad state of the nation's economy which has contributed to the hike in price of food items and other essential commodities, coupled with the growing rate of unemployment. The Nigerian government should use the opportunity created by the massive protests to execute a thorough reform of the Nigerian security establishments and also engage youths more productively in order to enable them to contribute their quota to nation-building.

\section{APA CITATION}

Owoaje, T. \& Sofola, K. (2021). The Clamour for an End to Police Brutality: Satire Songs of the EndSars Protests in Nigeria. East African Journal of Arts and Social Sciences, 3(1), 70-81. https://doi.org/10.37284/eajass.3.1.315 


\section{CHICAGO CITATION}

Owoaje, Tolu and Kadupe Sofola. 2021. "The Clamour for an End to Police Brutality: Satire Songs of the EndSars Protests in Nigeria". East African Journal of Arts and Social Sciences 3 (1), 70-81. https://doi.org/10.37284/eajass.3.1.315.

\section{HARVARD CITATION}

Owoaje, T \& Sofola, K. (2021) "The Clamour for an End to Police Brutality: Satire Songs of the EndSars Protests in Nigeria", East African Journal of Arts and Social Sciences, 3(1), pp. 70-81. doi: 10.37284/eajass.3.1.315.

\section{IEEE CITATION}

T Owoaje, K Sofola. "The Clamour for an End to Police Brutality: Satire Songs of the EndSars Protests in Nigeria", EAJASS, vol. 3, no. 1, pp. 70-81, Apr. 2021.

\section{MLA CITATION}

Owoaje, Tolu and Kadupe Sofola. "The Clamour for an End to Police Brutality: Satire Songs of the EndSars Protests in Nigeria". East African Journal of Arts and Social Sciences, Vol. 3, no. 1, Apr. 2021, pp. 70-81, doi:10.37284/eajass.3.1.315.

\section{INTRODUCTION}

Protest refers to collective action by a group of people with the aim of disapproving a move or policy, usually by the government or authority. Titus (2017) noted that protests whether peaceful or violent are not new occurrences in Nigeria. According to him, the country has been contending with protest from the pre-colonial era to colonial times and into the post-colonial era. Hari (2014) also explained that Nigeria had witnessed a series of protests mainly in the forms of general strikes, boycotts and mass demonstration organised and led by labour unions, youth movements and social activists to press home a variety of demands and grievances since it became an independent nation from its former colonial masters Britain in 1960. According to Okonkwo (1998), the notable earliest protests in Nigeria include protest action by Aba women in 1929, which was led by women in the provinces of Calabar and Owerri in south-eastern Nigeria in November and December 1929. The protest became known as Aba Women's Riots in British colonial history or as the Women's War in Igbo history. It was a revolt by thousands of Igbo women against policies imposed by British colonial administrators in south-eastern Nigeria.

The Women's War took months for the government to suppress and became a historic example of feminist and anti-colonial protest (Okonkwo, 1998, p. 23). Ina (1992) explained that the tax crisis of 1929 was a war and that it marked the end of the Warrant Chiefs system that was used to facilitate the British policy of indirect rule, and in particular, taxation. According to Ina, the war resulted in the inauguration of another phase of indirect rule; the
Native Authority system, which provided for the greater participation of the traditional rulers and the involvement of the educated elite in the local administration. He added that the involvement of the educated elite in the colonial administration allowed for more demands which resulted in more reforms.

Modern protests and revolutionary movements in Nigeria, especially those that make use of music, cannot be appropriately discussed without acknowledging the musical activism of Fela Anikulapo-Kuti. According to Labinjoh (1982), Fela was moved by the larger evolution of social consciousness that pervaded the black world in the 1960s, which made him choose to be a part of the politics of revolution that was consequent upon that fundamental change. The revolution that shaped his consciousness was the activities of the Black Americans in the United States at the time. Labinjoh further explained that Fela felt it more relevant to transfer his own revolutionary struggles to his own society where socio-historical conditions were different, obviously, from those of the United States since he was not an American citizen. It was then in the process of devising his own type of revolutionary struggle that is suitable to his social environment as well as the possibilities of his own existential condition that he chose music as his revolutionary instrument. Explaining Fela's choice of music as his instrument of revolutionary expression, Labinjoh posits that 'music, like other varieties of art, is located in the conjunction of structure and culture; music influences structure and culture and they in turn shape music' (Labinjoh, 1982, p. 120). 
Music has been extensively used by several Nigerian musicians as a medium of political expression. For many years, Nigerians have continued to clamour for good leadership and governance within a political environment that does not give room for the realisation of freedom of expression which is an integral part of democracy and as contained in the nation's constitution. Amidst this tight political environment, music has remained a medium through which the voice of the masses is communicated to the world. Apart from Fela Anikulapo, several other Nigerian musicians have employed the musical medium as a tool of expression against the problem of deficient leadership in the nation. Akande (2018) listed seven (7) songs by Nigerian musicians that demand a better Nigeria from the ruling class. The songs include "Zombie" by Fela Anikulapo Kuti, "Mr President by African China, "Which way Nigeria" by Sunny Okosun, "For Instance" by 2 face Idibia, "Jaga Jaga" by Eedris Abdulkareem, "E Wa Fun Mi Ni Visa" by Bembe Aladisa and "I Go Yarn" by Eldee. One of the most recent of such songs is "This is Nigeria" by Falz, a cover of Childish Gambino's "This Is America". Falz being a rapper, used the track to address the deteriorating state of the nation, which is also demonstrated in the video release of the song. It also includes the brutality of the Special Anti-Robbery Squad of the Nigerian Police Force. The song was later banned by the Nigerian Broadcasting Cooperation not long after its release in 2018 for being indecent and vulgar and also sparking reactions from religious organisations.

Titus (2017) investigated the use of music during Occupy Nigeria protest which was staged in reaction to the Nigerian government's removal of fuel subsidy in 2012. According to him, the use of music as a vital tool during the protest is connected to the cultural affiliation of Africans to music. In his words:

Musical performance in Africa maintains an integral relationship with other aspects of life. A notable feature of this interaction is the fact that music is often performed in a multimedia context in which dance, elaborate costumes, mime, poetry, and drama are featured in a total theatre spectacle. The location of this total theatre spectacle within the context of religious, social, and political activities underlies this indigenous perception of music. As an expressive idiom, it is characterised by an engaging interaction between professional musicians and communities (Titus, 2017).

Adokiya (2019) also identified music as a nonviolent tool for social activism. He explained that music is a part of human nature which aid in expressing emotions, helping in healing and creating a sense of unity and connection among communities. He further noted that the possibilities of music are expansive, which could be geared towards seeking peace if rightly channelled.

The need to put an end to police brutality in Nigeria gave birth to the EndSars protest. SARS is the Special Anti-Robbery Squad of the Nigerian Police, which has been described by Nigerian youths as being notorious for kidnapping, extortion and extrajudicial killing of citizens. The EndSars protest started on social media, particularly via Twitter, a popular microblogging service, with the hashtag \#EndSars. 'The \#EndSars hashtag was created to protest against the high handedness and human right abuse by men of the Special Anti-Robbery Squad (SARS), a unit of the Nigerian Police Force' (Oloyede \& Elega, 2019). It is important to note that this was not the first time such a protest was executed through social media. Other prominent hashtag activism in Nigeria includes \#OccupyNigeria and \#BringBackOurGirls. In October 2020, after several months of social media protest, the EndSars movement soon moved to the streets in various cities in Nigeria. The protest started in Lagos, proceeded to Abuja and then spread to major cities around the country, especially in the southern part of Nigeria. It soon caught the attention of international media while also drawing the attention of international human rights organisations.

During the course of the protest, music was extensively used by protesters in various ways. Satire songs were composed by various groups of protesters and used as protest songs which were sung at protest grounds and in the presence of the media. Some protesters also employed the service of the Disk Jockey who played a collection of Nigerian protest songs through sound equipment set in moving vehicles and on protest grounds. There is, therefore the need to investigate and document the 
use of music in the EndSars protests. This article investigates the use of satirical songs by protesters during the October 2020 EndSars protests. Primary data were generated through participant observation, as well as the use of social media platforms such as WhatsApp, YouTube and Twitter. Secondary data were generated from journal articles, books, print and electronic media. Collected songs were notated with the use of Avid Sibelius, a music writing tool, while the discussion of the songs was done through content analysis.

\section{SOCIAL MOVEMENTS AS A CONCEPT}

According to Menocal (2016), social movements are large, often informal groupings of people who come together against power-holders around a common cause in response to situations of perceived inequality, oppression and/or unmet social, political, economic or cultural demands. Tarrow (1994) explained that social movements are often one of the few (peaceful) options that people who lack regular access to institutions or who act in the name of new or unaccepted claims possess to challenge established rules of the game, thereby giving them their contentious character. Tarrow further noted that social movements emerge when political opportunities open up for social actors who usually lack them. 'Social movements prove effective when they build or illuminate solidarities that have shared meaning within particular groups, situations and political cultures and make them feel connected' (Menocal, 2016). According to Menocal, this involves mounting collective challenges, drawing on common purposes, and sustaining collective action across an extended period of time.

Le Bon, a French psychologist and founding father of collective action studies, regarded all street protest as a form of deviant behaviour. He developed the theory after studying crowds in France during the 1890s, which was a period of social unrest. Le Bon believed that the destruction of religious, political, and social beliefs in combination with the creation of new conditions of existence and thought, as a result of the modern scientific and industrial discoveries of the time, formed the basis of a process of transformation of the thought of mankind. He also believed that ideas from the past, although half destroyed, were still very powerful, while the ideas which are to replace them were still in the process of formation, thereby resulting in a period of transition and anarchy. According to Klandermans (1997), Le Bon regarded participation in collective action as an unconventional, irrational type of behaviour. Van Stekelenburg and Klandermans (2013) further noted that deprivation, shared grievances and generalised beliefs are determinants of participation in protests.

\section{Satirical Songs of the EndSars Protests}

Abrams and Harpham (2012), as cited in Adeleke (2016), defines satire as the "literary art of diminishing or derogating a subject by making it ridiculous and evoking towards it attitudes of amusement, contempt, scorn, or indignation.” Gray et al. (2009) view it as a subgenre of humour, which always has an element of social critique (p. 8). Giving the historical background of satire, Highet (1962) explained that satire emerged with primordial man and has been used extensively to order the behaviour of people in society. He further explained that satire was used in this manner since there were neither written laws nor prisons in the modern sense for the punishment of crimes in ancient time. Griffin (1973) also explained that individuals who committed crimes such as murder were subjected to physical torture, while those who committed minor offences such as stealing were punished through satirical attacks. Several studies (Yang \& Jiang 2015; Tang \& Bhattacharya, 2011; Esarey \& Qiang, 2008) have viewed parodies, jokes, slippery jingles, verse, songs and flash videos as political satire. Within the Nigerian political context, Femi Osofisan employs a great deal of music as an agent of political satire in his plays, which according to Adeleke (2016), has very little to do with governance nowadays but rather, with how much money one can make from politics and governance (p. 30). According to him, the songs of Osofisan satirise political leaders and the unjust economic system that breeds armed robbers. Furthermore, Adeleke noted that the satirical songs hold the different law enforcement agents up to ridicule and satirise all fake religious leaders. The intended purpose of the songs, as explained by Adeleke, is to 'enable everyone to examine himself or herself and make necessary amends where possible' (pg. 40). 
The EndSars protesters in their use of satirical songs during the protest attempted to use music as an object of ridicule against political leaders within a political atmosphere that is marred by massive corruption, unaccountability and irresponsibility. In addition, the fact that the Nigerian Police responded with more brutality when the protests started in various parts of the country and no action was taken by the government to discourage them from doing so further made the protesters see the government as more of a greater enemy than even the police which is known for highhandedness and extrajudicial killings. Hence the use of satirical songs to ridicule not only the Nigerian police but also the government.

\section{Police eh, go Sambisa eh}

Based on available video clips of the peaceful EndSars protests, as well as participatory observation, the song "Police eh, go Sambisa eh" is the most popular of the satirical songs used during the EndSars protest. Being directed to the Nigerian Police, the song, unlike all others, was specially composed as the theme song for the EndSars protest in Port-Harcourt, Nigeria. It is composed in Pidgin, being the most understood language of an average Nigerian police officer.
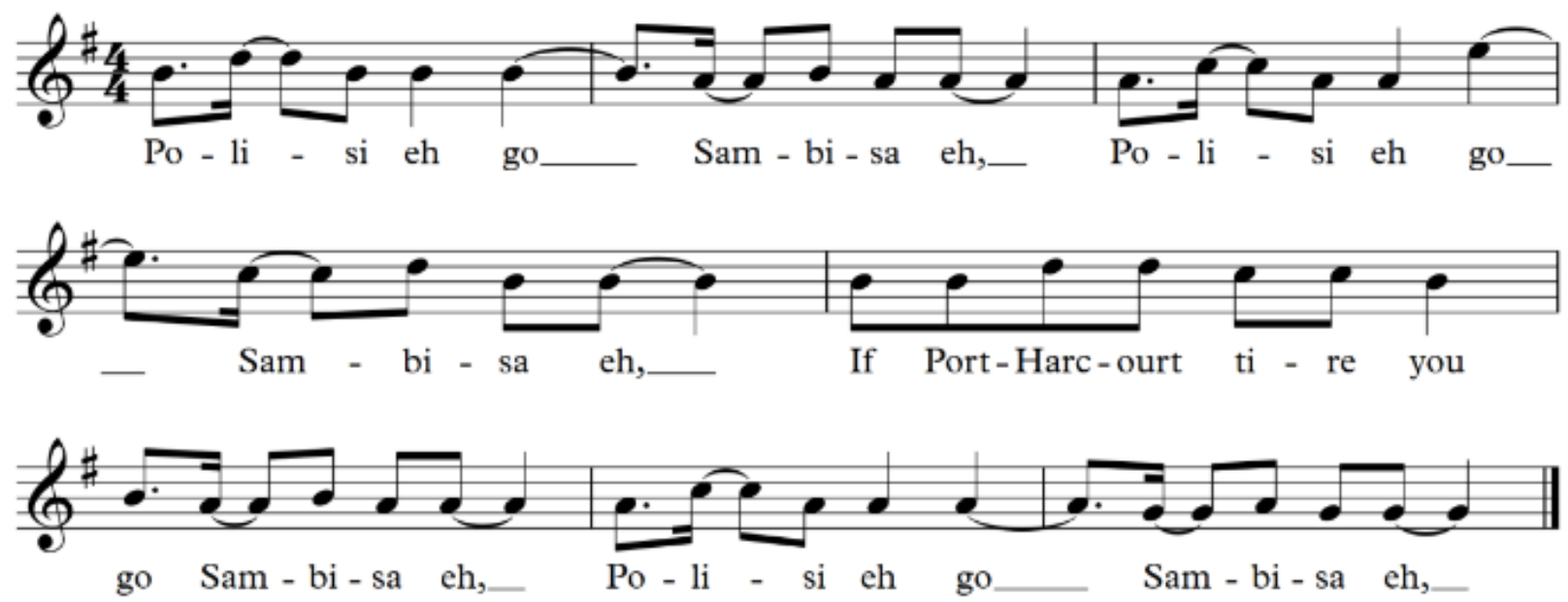

Nigerian Police, you can relocate to Sambisa

Nigerian Police, you can relocate to Sambisa

If you're tired of carrying out your duty ethically in Port-Harcourt

\section{Please consider redeployment to Sambisa}

Sambisa, as suggested as a better place of assignment for the brutal nature of the Nigerian police is the stronghold of the dreaded Boko-Haram terrorists, located in Borno state in Northern Nigeria. Boko-Haram is a terrorist group that has waged a bloody war against Nigeria for over ten years in a bid to impose its own brand of a religious order on the secular state (Olaniyan, 2018). Sambisa forest, before becoming a hideout for Boko-Haram terrorists was gazetted as a forest reserve by the British colonial administration in 1958. In 1977, the forest was re-gazetted as a National Game Reserve for the preservation of rare animals and as a way of generating funds from tourism (Olaniyan, 2018). Since the use of the Sambisa forest as a hideout by the dreaded Boko-Haram terrorists, it has turned into a war zone with military tanks and various troops of the Nigerian military.

The suggestion of Sambisa forest as a better place of redeployment for the Nigerian police's highhandedness is based on two factors. On the one hand, the Nigerian youths who have suffered brutality at the hands of the Nigerian police are harmless people who are treated like terrorists in broad daylight, especially by the Special Antirobbery Squad. The song is therefore used to ridicule the Nigerian police which cannot face terrorists but instead unleash terror on harmless youths. It presents the Nigerian police as a coward organisation that is not fit to face actual terrorists but instead delight pleasure in harassing and 
brutalising young people who go about looking for their daily bread in a peaceful manner. On the other hand, there was proSars protest staged in some part of the Northern region of the country during the EndSars protest. While the Southern and Middlebelt regions demanded an end to police brutality, especially the Special Anti-Robbery Squad, political leaders in the Northern region maintained a different stance. The song is, therefore a suggestion that the authorities should consider deploying the Special Anti-Robbery Squad to the Northern region where bandits and herdsmen keep killing and burning properties, and most especially, to Sambisa forest, where their brutish skills would be put to better use against armed terrorists who have been making life unbearable for people of the region, and in turn constituted a major security threat to the nation.

The song, alongside other popular Nigerian protest songs such as "Solidarity forever", was used as a marching song on the first day of the protest, as protesters move to converge at the front of Rivers state government house in Port-Harcourt.

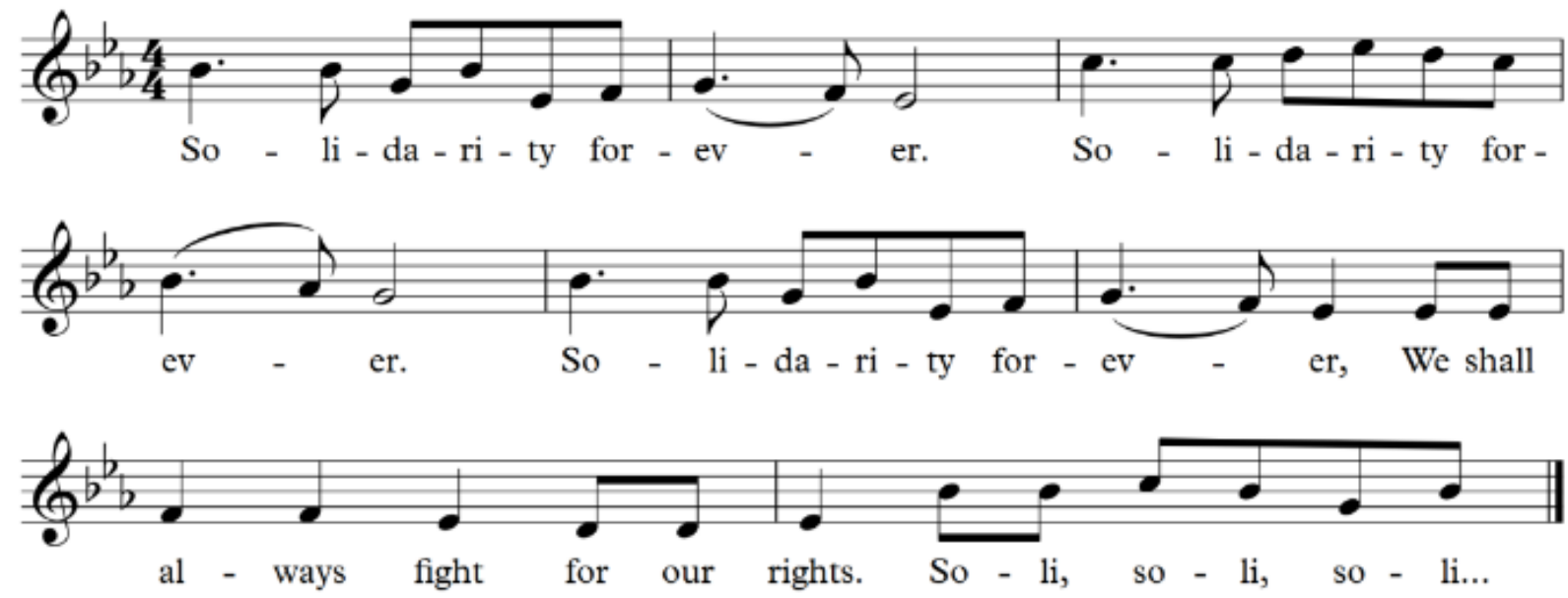

\section{How Many People Soldier Go Kill?}

The shooting that happened on the night of Tuesday, October 10 2020, at Lekki toll gate in Lagos during the EndSars protest, which resulted in the death and hospitalisation of protesters, sparked outrage the following day, as there were cases of a clash between civilians and police officers, burning and destruction of public and private properties and lots more in what could be regarded as a reaction to the killing of peaceful unarmed protesters. In the middle of this was yet another protest by heartbroken individuals who demanded an answer to questions bothering the military's involvement in the shooting of unarmed peaceful protesters. It was during this protest that the song "How many people soldier go kill" was sung to express anger at the alleged involvement of soldiers of the Nigerian Army in the shooting of peaceful unarmed protesters. 


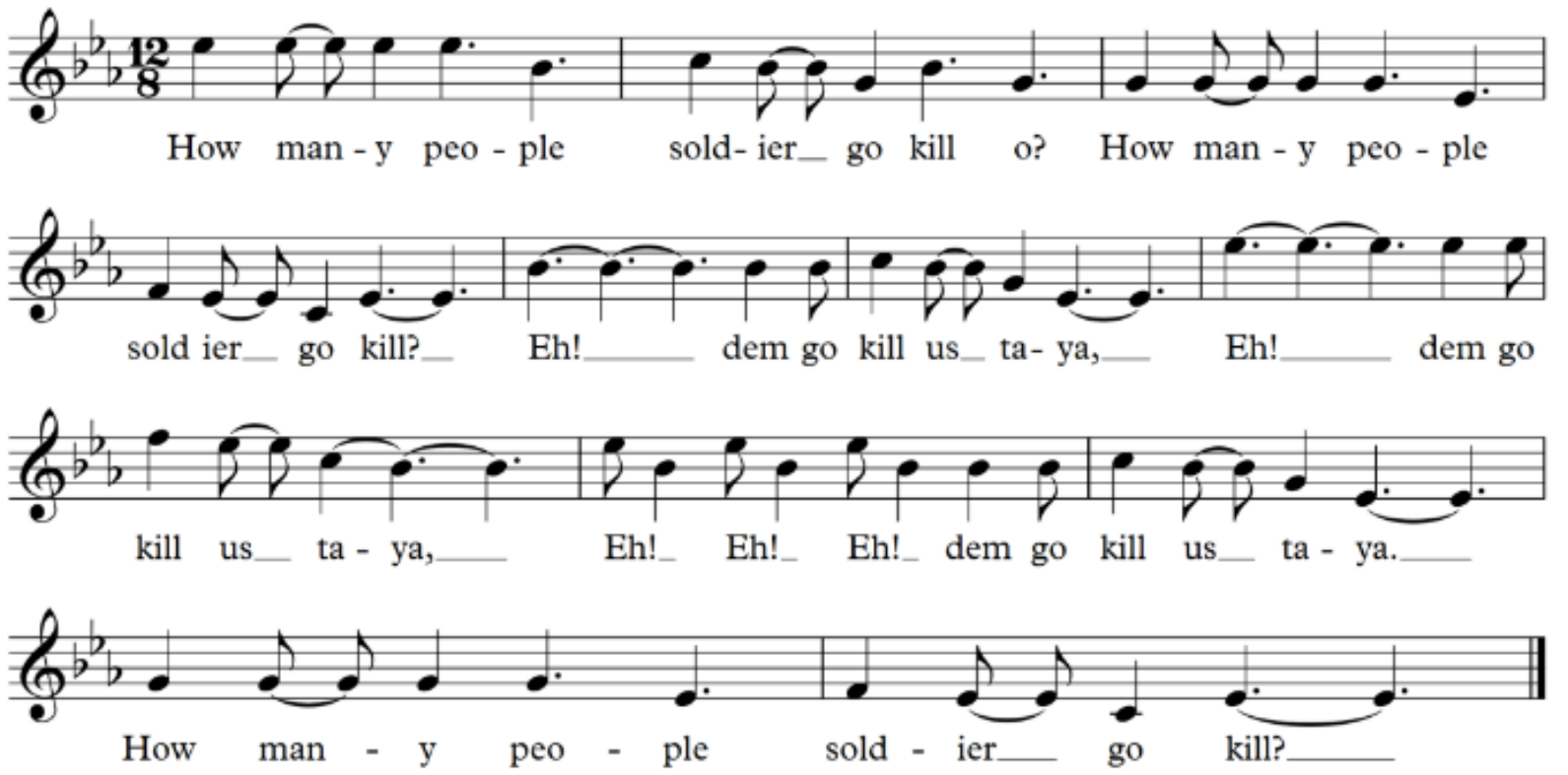

How many people can soldiers kill?

How many people can soldiers kill?

They will kill us until they are tired

They will kill us until they are tired

\section{How many people can soldiers kill?}

The song was chorused by the protesters as they express their anger at the unfortunate event, caring less of what the reaction of the authorities and of course, the military would be. The song is used as satire in order to mock the Nigerian military, tagging it as being good at clamping down on unarmed citizens. It also sends a message of courage to participants of the protest, maintaining that the military would not be confident enough to open fire on them in broad daylight, even as they are in their large number. In addition, the song also intends to send a signal to the Nigerian authorities that sending the military again this time around to stop the reactions of the protesters to the killing of unarmed protesters would be an exercise in futility, as the song suggests that protesters are not afraid of death.

During one of the protests in Ibadan, which took place at the gate of the state secretariat complex that houses the office of the governor, a group of youths upon convergence, rendered several protest songs which were a parody of existing Yoruba Christian songs. They substituted the original lyrics for newly composed lyrics which have been carefully woven together for the purpose of satirising the Nigerian government, as well as political leaders whom they believe have contributed to the problems and challenges being faced in the country. A clear examination of these songs indicates that their protest was more than aimed at putting an end to police brutality. Overall, it was a protest which demands an end to bad governance. 

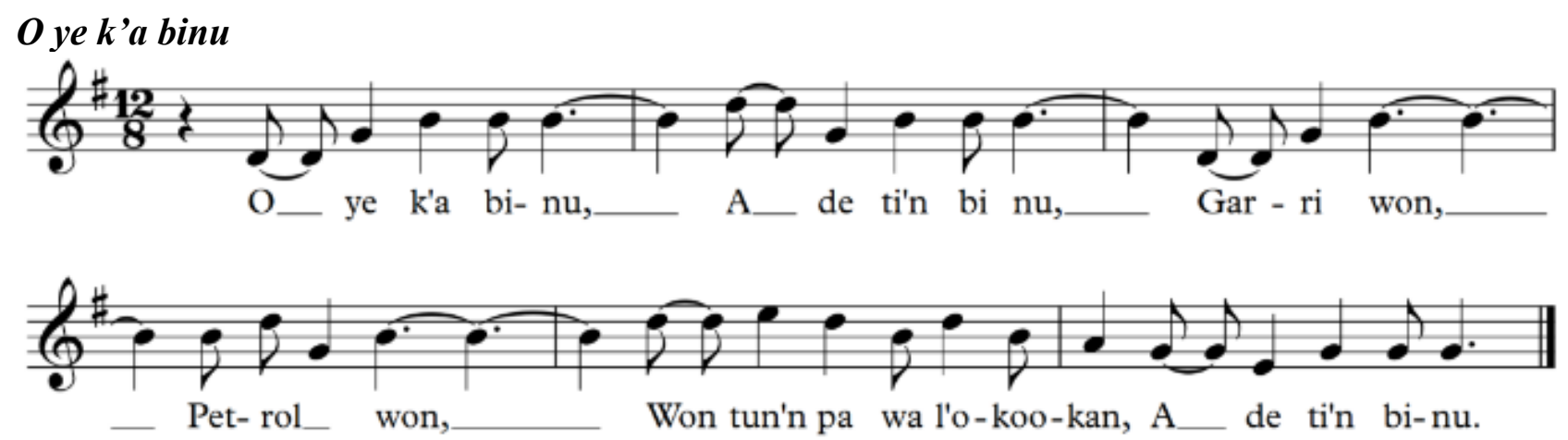

Our anger is long overdue

And now we are angry

Garri (cassava granules) has become so expensive

Petrol has also become so costly

And above all, the poor masses are being killed

Our anger is long overdue

"O ye k'a binu" (Our anger is long overdue) attempts to justify the anger of Nigerian youths as they voice out their anger through the protest. The song presents inflation in the price of commodities, as well as insecurity coupled with police brutality as justifiable reasons to get angry at the government since the suffering of the masses does not seem to bother the ruling class. Garri as mentioned in the song is used to represent the price of food generally. Garri is considered the most common and popular food item in Southern Nigeria, which is locally produced using cassava. It could be taken as a snack and could as well be soaked with milk, sugar and groundnut, depending on the preference of the consumer. It is also used in making $e b a$, when it is prepared with hot water. Garri is also considered the cheapest food item in the Nigerian food market, and it used to be affordable for both the poor and the rich. However, the price of garri has skyrocketed, that even the middle class can only afford to buy a small quantity with the same amount of money they once used in buying sufficient quantity. Early in the year, the government also increased the pump price of petroleum and introduced an increase in electricity tariff, among others. All of these are captured in the song "O ye k'a binu", thereby justifying the need for the protest.

\section{O ti yara gbagbe}

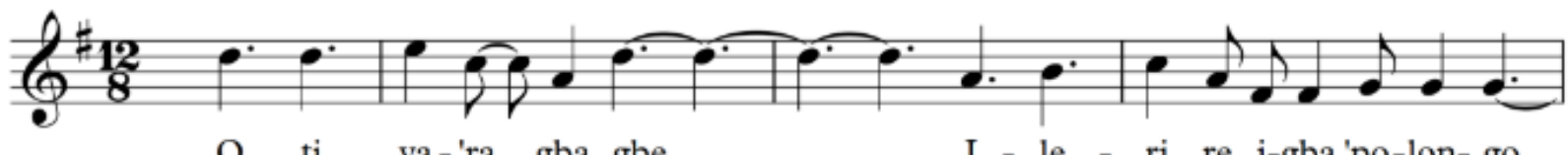

O ti ya-'ra_ gba gbe,

I - le - ri re i-gba'po-lon- go._

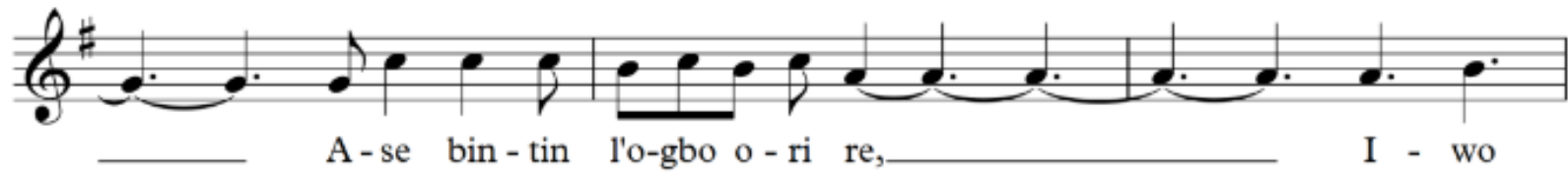



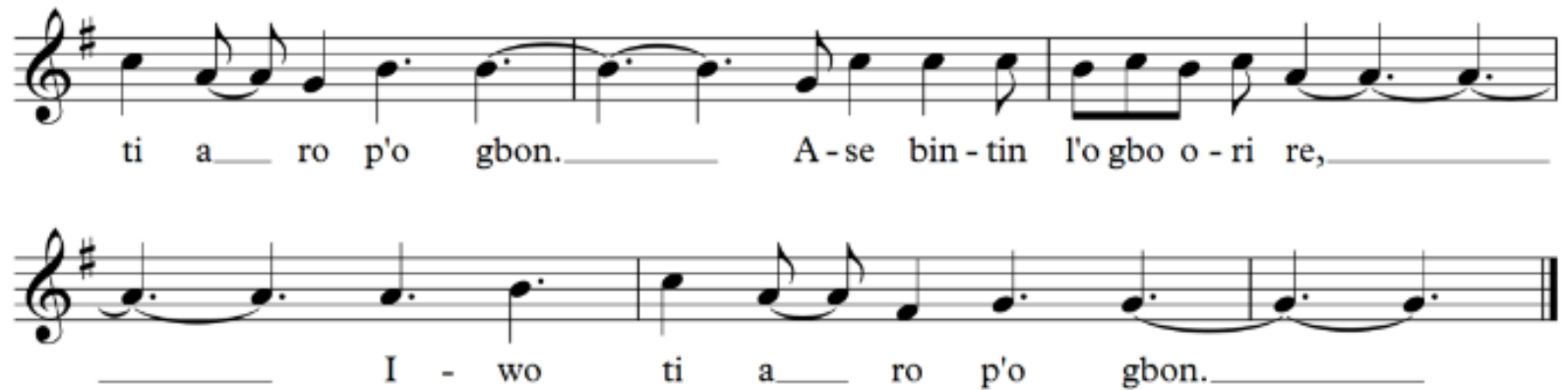

It is quite unfortunate

That you've suddenly forgotten your campaign promises

\section{We thought you were so intelligent}

\section{But we were wrong}

"O ti yara gbagbe" centres on the habitual practice of Nigerian politicians in neglecting their campaign promises. It expresses disappointment in the way and manner in which the current government at the central have distanced itself from its electoral promises which include; ending the Boko-Haram insurgency within months and also eradicating insecurity, reducing the pump price of petroleum, creating jobs in millions, fighting corruption and strengthening electoral process among others. It is worthy of note that these campaign promises to date have largely not been kept by the current administration. According to the song, the Vice President being a Professor of Law and the President being a former Head of State were initially believed to be capable of bringing the desired change needed to move the country forward. The song, as performed by the protesters, is repeated several times, with the shout of "Buhari" or "Osinbajo" as a call to start singing again from the beginning, thereby expressing disappointment in the anticipated quality of the duo in leading the nation to greater heights.

\section{Gbogbo won l'o lowo mbe}

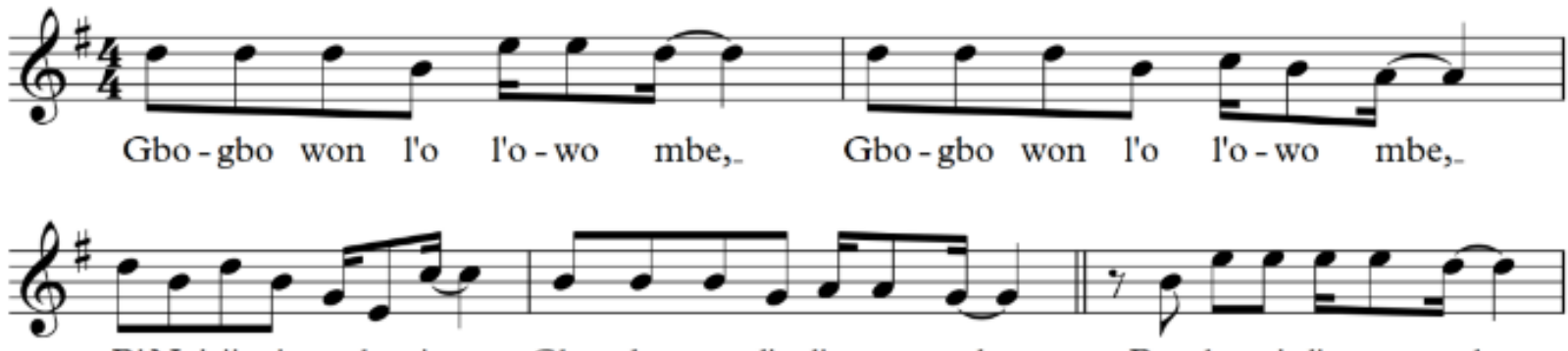

BiNai-ji-ria se ba-je,_ Gbo-gbo won l'o l'o-wo mbe. Bu-ha-ri l'o-wo mbe,

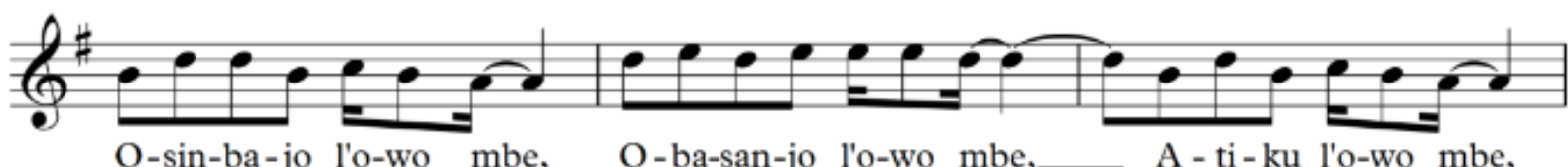

O-sin-ba-jo l'o-wo mbe, O-ba-san-jo l'o-wo mbe,__ A-ti-ku l'o-wo mbe,

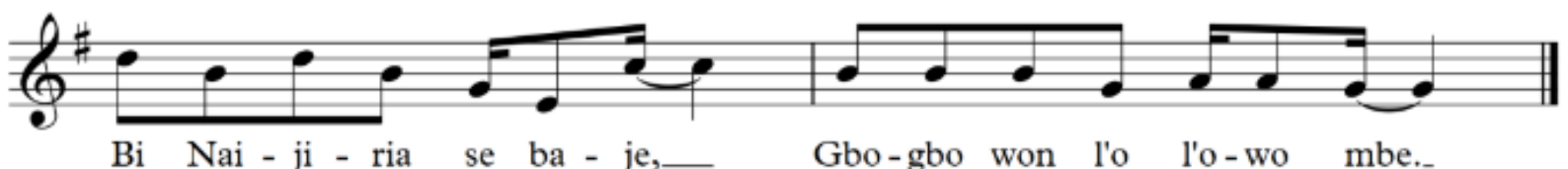

They all contributed to the destruction of Nigeria
Buhari contributed his quota

Osinbajo played his part 
East African Journal of Arts and Social Sciences, Volume 3, Issue 1, 2021

Article DOI: https://doi.org/10.37284/eajass.3.1.315

Obasanjo played a vital role

Atiku is also an accomplice

\section{In the destruction of Nigeria}

There is no gainsaying in the fact that development in any country is a gradual progressive effort by different governments, which builds up over time. In other words, lack of development could be attributed to accumulated failure by various successive governments. It is within this context that the song "Gbogbo won lo lowo mbe" links the massive systemic failure in the country to leaders, both past and present. For instance, the problem of epileptic power supply did not start with the current government; neither did it start with the immediate past government. It is a result of accumulated failure in the power sector, which has remained a national challenge. Similarly, the problem of police brutality has lingered since the military regimes into two decades of democratic rule. For instance, Fela suffered series of police brutality during the military regimes and also sang about the highhandedness of the police at the time.

Davido's "Fem" (Shut up) also featured as an instrument of satire during the EndSars protest in Lagos. The song was used to interrupt the governor of Lagos State, Mr Babajide Sanwoolu, while he was addressing protesters at the state secretariat in Ikeja, Lagos. A video documentation of the event shows the protesters chorusing the song " $\mathrm{Fem}$ " after the Disc Jockey had played it through the public address system to interrupt the governor's address. Below is the section of the song that was used in this regard.

E be like you don dey talk too much

You seem to talk too much

Small talk you don dey talk who talk

You are too inquisitive

Fem (Baddest)

Keep quiet!

O boy you don dey do too much

Guy, you talk too much

Small talk you don dey look who talk

You are too inquisitive
Fem

Keep quiet!

Person wey dey find the pity

One who wants to be pitied

Omo no dey give me itty bitty

Don't make me feel guilty

Just call me, you wan know $30 B G$

Just try and make your point clear

You go know $30 B G$ when you see $30 B G$ The truth is always direct, without mincing words

Aahh Haaa ahn.........

Aahh Haaa ahn......

The message conveyed by the song requires one to make his point, rather than beating around the bush, as too much word could mean an attempt to cover up something or arouse unnecessary sympathy.

\section{CONCLUSION}

The EndSars protest became necessary in order to put an end to police brutality in Nigeria, and most especially, the highhandedness of the notorious Special Anti-Robbery Squad of the Nigerian Police Force (SARS), which have been alleged of kidnapping, killing and harassing innocent Nigerian citizens. The EndSars protest started on social media, particularly via Twitter, a popular microblogging service, with the hashtag \#EndSars. In October 2020, after several months of social media protest, the EndSars movement moved to the streets in various cities in Nigeria. During the course of the protest, music was extensively used by protesters in various ways, which includes the use of satirical songs which were composed by various groups of protesters and used as protest songs that were sung at protest grounds and in the presence of the media. Protesters used the songs to express their long-overdue anger at the Federal Government of Nigeria due to several unfulfilled campaign promises, as well as the bad state of the nation's economy which has contributed to the hike in price of food items, fuel, electricity and lots more, coupled with the growing rate of unemployment. Satirical songs used during the protest also aimed at expressing disappointment at the President and his Vice, both being former Head of State and Professor 
of Law, respectively. Finally, the satirical songs of the EndSars protest aimed at presenting political leaders as objects of ridicule in order to enable them to make amends where necessary. The EndSars protest is, therefore, a metaphorical reaction to what the Nigerian youths generally perceive as issues pertaining to bad governance in Nigeria. The Nigerian government should use the opportunity created by the massive protests to execute a thorough reform of the Nigerian security establishments and also engage youths more productively in order to enable them to contribute their quota to nation-building.

\section{REFERENCES}

Abrams, M. H. and Harpham, G. G. (2012). A Glossary of Literary Terms. (10th Ed.). Boston: Centage.

Adeleke, D. (2020). "Fem" [Video file]. Dapche and Dammy Twitch Prod.: Lagos. Retrieved fromhttps://www.youtube.com/watch?v=lta5go 9P-go

Adeleke, E., B. (2016). Music as an Agent of Satire in Selected Plays of Femi Osofisan. Africology: The Journal of Pan African Studies, 9(2), 28-41.

Adokiya, O. P. (2019). Music, a non-violent tool for social activism: A case study of River state. Journal of the Association of Nigerian Musicologists, 13, 155-168.

Akande, S. (2018). How To Ask For A Better Nigeria, In 7 Songs. Reviewed on November 9, 2020,https://staging.zikoko.com/life/citizen/ho w-to-ask-for-a-better-nigeria-in-7-songs/

Esarey, A., \& Qiang, X. (2008). Political expression in the Chinese blogosphere: Below the radar. Asian Survey, 48(5), 752-772.

Falana, F. (2018). "This is Nigeria" [Video file]. Wande Thomas Prod.: Lagos. Retrieved from https://www.youtube.com/watch?list=RDVYOj WnS4cMY\&v=UW_xEqCWrm0

Gray, J., Jones, J., and Thompson, E., (2009). The State of Satire, the Satire of State. In: Gray, J., Jones, J. \& Thompson, E. (eds), Satire TV:
Politics and Comedy in the Post-Network Era (pp. 3-36). New York: NYU Press.

Griffin, D. (1973). Satires Against Man: The Poems of Rocherster. Berkeley: California UP

Hari, S. I. (2014). The evolution of social protest in Nigeria: The role of social media in the "\# OccupyNigeria" protest. International Journal of Humanities and Social Science Invention, 3(9), 33-39.

Highet, G. (1962). The Anatomy of Satire. Princeton: Princeton UP.

Ina, K. E. (1992). The Tax Crisis of 1929 in Ibibioland. Transafrican Journal of History, 171-181.

Klandermans, P. G. (1997). The social psychology of protest. Oxford: Blackwell

Labinjoh, J. (1982). Fela Anikulapo-Kuti: Protest music and social processes in Nigeria. Journal of Black Studies, 13(1), 119-134.

Menocal, R. A. (2016). Social movements. GSDRC Professional Development Reading Pack no. 50. Birmingham, UK: University of Birmingham.

Okonkwo, R. (1998). Protest Movement in Lagos: 1908-1930. Lagos: Edwin Mellen Press.

Olaniyan, A. (2018). Once Upon a Game Reserve: Sambisa and the Tragedy of a Forested Landscape. Arcadia, 2. Rachel Carson Center for Environment and Society.

Oloyede, F., \& Elega, A.A (2019) Exploring Hashtag Activism in Nigeria: A case of \#EndSars Campaign. Conference Proceeding: 5th In Communication and Media Studies (CRPC 2018), Famagusta, Turkish Republic of Northern Cyprus.

Tang, L., \& Bhattacharya, S. (2011). Power and resistance: A case study of satire on the Internet. Sociological Research Online, 16(2), 10-18.

Tarrow, S. (1994). Introduction. In Power in movement: Social movements and contentious 
politics (pp. 1-28). Cambridge, UK: Cambridge University Press.

Tarrow, S. (1994). Social movements in Europe: Movement society or Europeanization of conflict? EUI Working Paper RSC No. 94/8. San Domenico, FI: European University Institute, Badia Fiesolana,

This Is Nigeria. In Wikipedia, The Free Encyclopedia. Retrieved 11:59, November 18, 2020 ,

from https://en.wikipedia.org/w/index.php?title $=$ This_Is_Nigeria\&oldid=985047768

Titus, O. S. (2017). From Social Media Space to Sound Space: Protest Songs during Occupy Nigeria Fuel Subsidy Removal. Muziki, 14(2), 109-128.

Van Stekelenburg, J., \& Klandermans, B. (2013). The social psychology of protest. Current Sociology, 61(5-6), 886-905.

Van Stekelenburg, J., \& Klandermans, B. (2017). Individuals in movements: A social psychology of contention. In Handbook of social movements across disciplines (pp. 103-139). Springer, Cham.

Yang, G., \& Jiang, M. (2015). The networked practice of online political satire in China: Between ritual and resistance. International Communication Gazette, 77(3), 215-231. 